\title{
Expression of vascular endothelial growth factor and receptor flk-1 in colon cancer liver metastases
}

\author{
Jun Cheng ${ }^{1}$, Richard E. Slavin ${ }^{2}$, Jennifer A. Gallagher ${ }^{2}$, Guojing Zhu ${ }^{2}$, Thomas R. Biehl ${ }^{3}$, \\ Lee L. Swanstrom ${ }^{2}$, and Paul D. Hansen ${ }^{2}$ \\ ${ }^{1}$ General Surgery, TC-2926D, University of Michigan Health System, 1500 E. Medical Center Dr., Ann Arbor, MI 48109, USA \\ ${ }^{2}$ Legacy Health System, Portland, OR, USA \\ ${ }^{3}$ Virginia Mason Medical Center, Seattle, WA, USA
}

\begin{abstract}
Background/Purpose. This study investigated vascular endothelial growth factor (VEGF) and flk-1 expression in hepatic metastases from colon carcinoma, and their associations with tumor angiogenesis, proliferation, and apoptosis.

Methods. Immunohistochemical studies were performed for VEGF/flk-1, Ki-67, p53, and bcl-2 expression, and microvessel density (MVD) in surgical specimens from 35 patients who underwent hepatectomy for colon cancer liver metastases between 1986 and 2001.

Results. VEGF and flk-1 were expressed mainly in the cytoplasm of tumor cells. High VEGF expression was associated with high flk-1 expression $(P=0.043)$. MVDs of less than 15 and 15 or more were found in $5(14.3 \%)$ and $30(85.7 \%)$ of 35 hepatic metastases, respectively. A Ki-67 index (KI) of $50 \%$ or more was detected in 33/35 (94.3\%) of tumors, and 23 of these $(65.7 \%)$ showed a KI of $85 \%$ or more. A KI of less than $50 \%$ was present in $2 / 35(5.7 \%)$ of tumors. The expression of VEGF/flk-1 was related to elevated MVD $(P \leq 0.026)$. VEGF was also associated with an increased KI $(P=0.025)$. Mutant p53 and bcl-2 expressions were detected in 26/35 (74.3\%) and $17 / 35(48.6 \%)$ of liver metastases, respectively. Mutant p53 was not related to VEGF/flk-1 expression, but bcl-2 was highly associated with flk-1 $(P=0.007)$. The incidences of high flk-1 expression and a $\mathrm{KI}$ of $85 \%$ or more were significantly higher in tumors which were both p53- and bcl-2-positive (93.3\% and $73.3 \%)$ than in tumors which were negative for both $(42.9 \%$ and $14.3 \% ; P \leq 0.021$.

Conclusions. The VEGF-flk-1 system takes part in tumor angiogenesis, proliferation, and apoptosis in colon liver metastases. The bcl-2 pathway may upregulate VEGF activity via the flk-1 receptor. These findings are preliminary, requiring a larger sampling in order to elucidate the role of $\mathrm{VEGF} / \mathrm{flk}-1$ in metastatic colon cancer.
\end{abstract}

Offprint requests to: J. Cheng

Presented at the 89th Annual Clinical Congress of the American College of Surgeons, Chicago, IL, USA, October 19-23, 2003.

Received: June 20, 2003 / Accepted: November 12, 2003
Key words VEGF/flk-1 • Colon cancer liver metastases · Angiogenesis $\cdot$ Proliferation $\cdot$ Apoptosis

\section{Introdcution}

Colorectal carcinoma is the third-leading cause of cancer deaths in the United States. Up to $60 \%$ of patients with colon cancer will eventually develop liver metastases. Progression of such hepatic metastases is the major cause of death in these patients. It is recognized that tumor metastasis and progression are angiogenesisdependent. ${ }^{1}$ An avascular tumor rarely grows larger than 2 to $3 \mathrm{~mm}^{3}$, but, once vascularized, tumor progression is rapid. ${ }^{2}$ The angiogenic process includes cell migration, proliferation, extracellular matrix degradation, and structural reorganization. ${ }^{3}$ These steps are regulated by the balance of proangiogenic and antiangiogenic molecules and their receptors. ${ }^{3}$ One potent proangiogenic factor is vascular endothelial growth factor (VEGF) that can be synthesized and secreted by both tumor and host cells. VEGF is a homodimeric 34to $42-\mathrm{kDa}$ heparin-binding glycoprotein with mitogenic and vascular permeability-enhancing activities for endothelial cells. ${ }^{4}$ Its activity is mediated by two highaffinity tyrosine-kinase receptors, fms-like tyrosine kinase (flt-1) and fetal liver kinase-1 (flk-1): flk-1 is a major regulator of angiogenesis, both in vitro and in vivo. ${ }^{4,5}$

The $p 53$ tumor suppressor gene is the most commonly mutated gene in human cancer. It is correlated to poor prognosis in colon cancer. ${ }^{6,7} \mathrm{bcl}-2$ is a tumor protooncogene that contributes to the development and progression of colon cancer. ${ }^{8}$ Both the $p 53$ gene and the bcl-2 gene are involved in the regulation of apoptosis (programmed cell death) ${ }^{6}$ and VEGF expression. ${ }^{1,8,9} \mathrm{Ki}^{-}$ 67 nuclear antigen is evident in all active phases of the cell cycle, and its expression is utilized as an indicator of 
tumor proliferation. ${ }^{10}$ In order to further understand the role of VEGF/flk-1 in tumor angiogenesis, proliferation, and apoptosis, we hypothesized that hepatic metastases from colon cancer may overexpress VEGF and flk-1, and their expressions may be associated with tumor angiogenesis, proliferation, and apoptosis markers. This study was designed to test this hypothesis in surgical archival specimens of colorectal hepatic metastases.

\section{Patients, materials, and methods}

The clinical and pathologic data from 35 patients with colon carcinoma liver metastases, who underwent partial hepatectomy between 1986 and 2001, were reviewed. A representative formalin-fixed paraffinembedded block containing both cancer and adjacent noncancerous liver was selected from each case. Normal liver away from the tumor margins served as internal controls. Consecutive 4- $\mu \mathrm{m}$ sections were cut from each selected histological block, mounted on positively charged slides, and allowed to dry in an oven at $60^{\circ} \mathrm{C}$ overnight. Sections were deparaffinized in xylene, followed by $99.99 \%, 95 \%$, and $80 \%$ isopropyl alcohol (Fisher Scientific, Pittsburgh, PA, USA) and rehydrated in tap water. For antigen retrieval, these sections were immersed in $1 \times$ citrate buffer ( $\mathrm{pH}$ 6.0; Biocare Medical, Walnut Creek, CA, USA) for VEGF and p53, $1 \times$ reveal buffer ( $\mathrm{pH}$ 6.0; Biocare Medical) for flk-1, BORG buffer ( $\mathrm{pH}$ 9.5; Biocare Medical) for CD31, and $1 \times$ Tris buffer ( $\mathrm{pH}$ 9.5; Biocare Medical) for Ki-67 and bcl-2, and boiled for $8 \mathrm{~min}$ in a pressure cooker (Decloaking Chamber; Biocare Medical). This procedure unmasked the epitopes from the formalin bonds, allowing better antibody recognition. Endogenous peroxidase activity was quenched with $3 \%$ hydrogen peroxide $\left(\mathrm{H}_{2} \mathrm{O}_{2}\right)$.

Immunohistochemical staining (IHC) was performed with the streptavidin-biotin method, using a Ventana NEXES automated immunostainer (Ventana Medical Systems, Tucson, AZ, USA). Mouse monoclonal primary antibodies were used for VEGF (sc-7269, $\operatorname{IgG}_{2 \mathrm{a}}$; Santa Cruz Biotechnology, Santa Cruz, CA, USA; 1:150 dilution), flk-1 (sc-6251, IgG ; $_{1}$ Santa Cruz Biotechnology; 1:100 dilution), human endothelial cells (CD31; clone JC/70A, $\mathrm{IgG}_{1}$; DAKO, Carpinteria, CA,

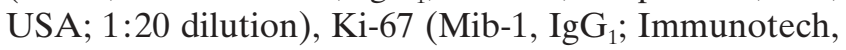
Beckman Coulter, Marseille, France; 1:40 dilution), p53 (clone DO-7, IgG $\mathrm{Ig}_{2 \mathrm{~b}}$; DAKO, labeling both wildtype and mutant p53 protein, 1:100 dilution), bcl-2 (clone 124, $\operatorname{IgG}_{1}$; DAKO, 1:40 dilution), and carcinoembryonic antigen (CEA; clone CEJ065, IgG; Immunotech, prediluted). The secondary antibody, biotinylated goat antimouse and rabbit IgG (Biocare Medical) and a tertiary label with streptavidin-horseradish peroxidase (HRP) complex were added auto- matically. The immunoperoxidase staining was developed using 3,3'-diaminobenzidine tetrahydrochloride (DAB). Negative controls were prepared by omitting the primary antibody and substitution with an irrelevant mouse antibody. Tissues known to express selected antigens were selected as positive controls for each antibody (breast carcinoma for VEGF and CD31, colon cancer for flk-1, lymph nodes for Ki-67 and bcl-2, and squamous cell carcinoma for p53). All slides were counterstained with hematoxylin and mounted with coverslipping film (Tissue-Tek, Sakura, Japan).

The intensity of VEGF/flk-1 and CEA staining was assessed semiquantitatively under a light microscope, using a score of 0 to $3+$ : 0 , negative; $1+$, weak or low intensity; $2+$, intermediate or moderate intensity; and $3+$, strong or high intensity. For analyses, VEGF/flk-1 expression was classified as "low" if the score was 0 or $1+$; or "high" if the score was $2+$ or $3+.{ }^{11}$ The intensity was judged relative to an intensely stained positive control $(3+)$. Homogeneity of staining was determined, together with the localization of staining and its reproducibility.

Microvessel density (MVD) is an index of angiogenesis and was assessed using a technique modified from those of Weidner et al. ${ }^{12}$ and Vermeulen et al. ${ }^{13}$ The entire section was systematically scanned at a magnification of $\times 100$ to search for areas of intense neovascularization at the tumor-liver interface, commonly called "hot spots" (Fig. 1A). These were identified as having the highest density of brown-staining, CD31-positive cells or cell clusters. Whenever a highly vascularized area was evident at magnification $\times 100$, the individual microvessels were counted on a single $\times 200$ field in this area, using a light microscope-monitor system (Color Video Printer; UP-5600MD; Sony, Tokyo, Japan). Any brown-stained structure clearly separated from adjacent microvessels was regarded as a single countable microvessel. Neither vessel lumen nor the presence of red blood cells was used to define a microvessel, and exclusion criteria based on size were not used. The mean microvessel count of five $\times 200$ fields per sample determined a tumor MVD.

Proliferation activity of cancer cells were evaluated by the Ki-67 index (KI). The KI was calculated as the percentage of tumor cells staining positive with $\mathrm{Ki}-67$ antibody in ten fields at magnification $\times 400$. The expression of p53 and that of bcl-2 were considered positive if greater than $10 \%$ of cancer cells demonstrating staining. ${ }^{13,14}$ The percentages of $\mathrm{Ki}-67, \mathrm{p} 53$, and bcl-2 expression were also counted under the light microscope-monitor system. Hematoxylin-and-eosin staining was performed for histopathological assessment.

For quality control, MVD and KI were counted by an independent investigator, and the staining results were evaluated independently at the same calibration slides 


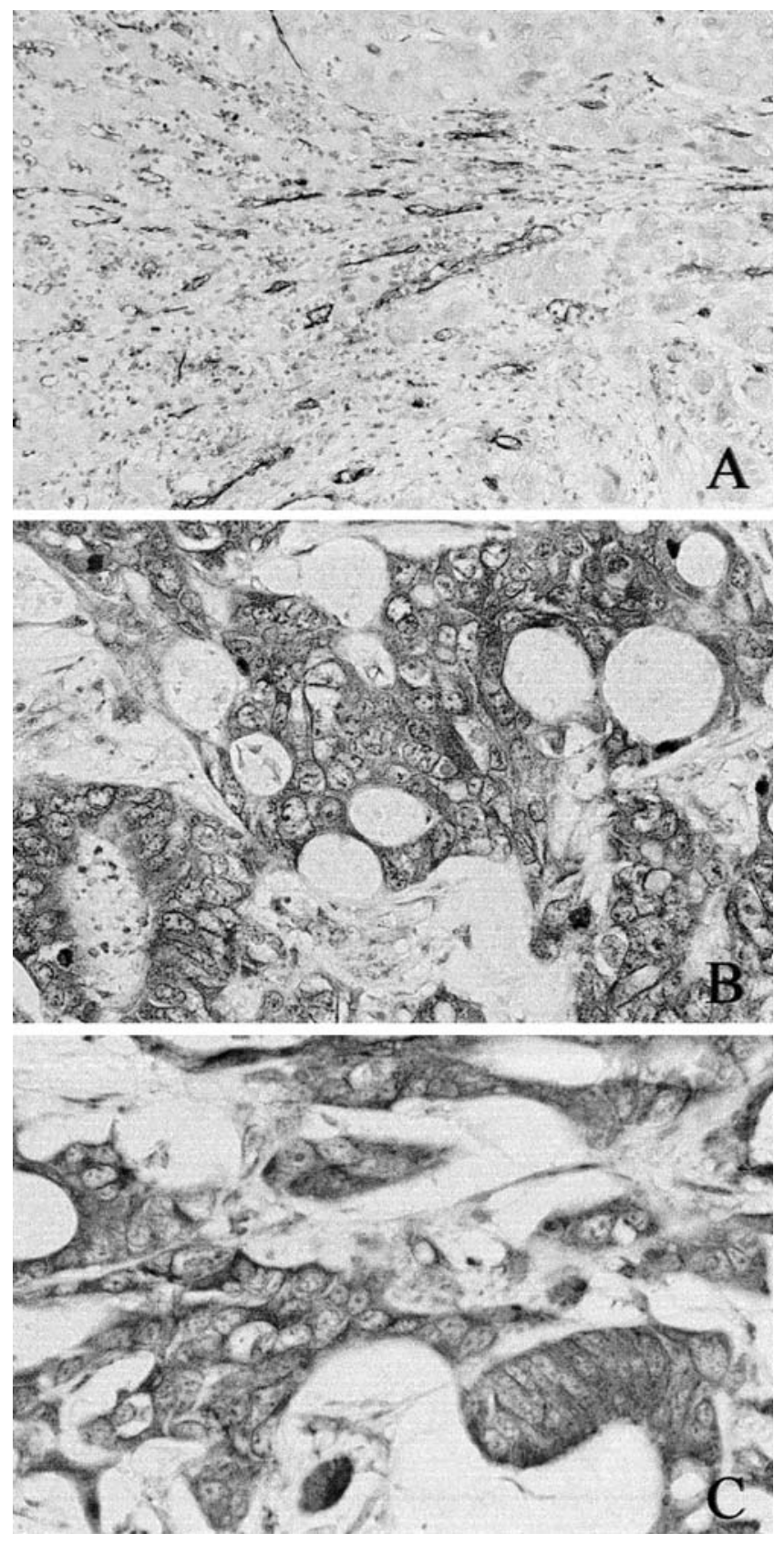

Fig. 1A-C. Microvessel density (MVD) was counted at the tumor-liver interface "hot spot" (A), as an index of angiogenesis. Strong cytoplasmic staining $(3+)$ for vascular endothelial growth factor (VEGF) (B) and flk-1 (C) was present in hepatic metastatic tumor cells from colon cancer. $\mathbf{A} \times 200 ; \mathbf{B}, \mathbf{C}$ $\times 400$

by two investigators. Every investigator was blinded to every other investigator's interpretation and the patient outcome, and each investigator was also unaware of each marker evaluation score. The results for flk-1, p53, bcl-2, and CEA were concordant. The agreement for VEGF was $97.1 \%$, and a final result was obtained by consensus in one case.
Clinical and pathological features collected included age, sex, type of hepatic metastases (synchronus vs metachronous), tumor number, largest size, lobar distribution (unilobar vs bilobar), and differentiation (defined as well-, moderately, or poorly differentiated).

Values are given as numbers and/or percentages. The Fisher exact test was used for statistical analysis (Primer of biostatistics, McGraw-Hill, 1997). Statistical significance was considered at $P<0.05$.

\section{Results}

The 35 patients included 16 men and 19 women, with a mean age of 61 years (range, 39-76 years). All patients underwent partial hepatectomy. Thirty-one of 35 $(88.6 \%)$ specimens were from metachronous hepatic metastases, and $4(11.4 \%)$ were from synchronous metastases. Nineteen of $35(54.3 \%)$ patients had a single tumor and $16(45.7 \%)$ patients had multiple $(\geq 2)$ tumors. In $27(77.1 \%)$ patients the tumors were unilobar, while in $8(22.9 \%)$ patients they were bilobar. The mean largest tumor size was $5.3 \mathrm{~cm}$ (median, $5.0 \mathrm{~cm}$; range, $1.0-12.5 \mathrm{~cm}$ ). Tumor size of less than $4 \mathrm{~cm}$ was found in $13(37.1 \%)$ patients, and a size of $4 \mathrm{~cm}$ or more in 22 $(62.9 \%)$ patients. The tumors were moderately differentiated in $27(77.1 \%)$ cases and $8(22.9 \%)$ were poorly differentiated.

All cases stained strongly for CEA (2 to $3+$ ). Both VEGF and flk-1 exhibited predominantly cytoplasmic staining in tumor cells (Fig. 1B,C), but VEGF immunoreactivity also showed a heterogeneous staining pattern, with both cytoplasmic and nuclear staining in 12 of $35(34.3 \%)$ cases. VEGF was more frequently expressed in cancer tissue than in adjacent liver tissue. Some tumor samples showed a gradient of increased intensity toward the infiltrating edge of the tumor cells. VEGF expression was "high" $(2+/ 3+)$ in 29 of 35 $(82.9 \%)$ and "low" $(0 / 1+)$ in $6 / 35(17.1 \%)$. Flk-1 expression was "high" in 25/35 (71.4\%) and "low" in 10/35 $(28.6 \%)$. The statistical test showed a significant association between increased VEGF and flk-1 expressions $(P=0.043$; Table 1$)$. VEGF and flk-1 were also expressed in the endothelial cells.

Tumor MVD of less than 15 was found in 5 of 35 (14.3\%) hepatic metastases and an MVD of 15 or more was observed in $30(85.7 \%)$ tumors. KI values of $50 \%$ or more and $85 \%$ or more were detected in $33 / 35(94.3 \%)$ and $23 / 35(65.7 \%)$ tumors, respectively. Only $2 / 35$ $(5.7 \%)$ of metastases showed a KI values of less than $50 \%$. The expression of both VEGF and flk-1 was strongly related to MVD $(P \leq 0.026)$. There was also an association between VEGF and KI $(P=0.025$; Table 2$)$.

Positive nuclear staining for $\mathrm{p} 53$ was detected in 26 of $35(74.3 \%)$ cases. The p53 nuclear staining was diffuse, 
with little variation. p53-positivity and high VEGF expression coexisted in 20 of $35(57.1 \%)$ patients. There were no cases showing both p53 negativity and low VEGF expression. Immunoreactivity for bcl-2 was mainly cytoplasmic, and was principally localized to the apical portion of the tumor cells. Seventeen $(48.6 \%)$ tumors were bcl-2 positive and $18(51.4 \%)$ were negative. There was no relationship between 553 or bcl-2 and the KI $(P \geq 0.486)$. Both $\mathrm{p} 53$ and bcl-2 positivity $\left(\mathrm{p} 53^{+} / \mathrm{bcl}-2^{+}\right)$was observed in 15 of $35(42.9 \%)$ tumors, and both p53 and bcl-2 negativity (p53-/bcl-2-) was observed in 7 (20.0\%; Table 3). Expression of VEGF showed no association with either p53 or bcl-2 $(P=$

Table 1. Association between VEGF and flk-1 expression

\begin{tabular}{lcc}
\hline & \multicolumn{2}{c}{ VEGF } \\
\cline { 2 - 3 } flk-1 & Low $(-/ 1+)$ & High $(2+/ 3+)$ \\
\hline Low $(-/ 1+)$ & 4 & 6 \\
High $(2+/ 3+)$ & 2 & 23 \\
\hline
\end{tabular}

$\overline{\text { The Fisher exact test showed a linear trend between vascular endothe- }}$ lial growth factor (VEGF) and flk-1 expression; $P=0.043$
0.304 and $P=0.658$, respectively; Table 2). flk-1 expression was significantly related to bcl-2 expression at a direct level ratio $(P=0.007)$, but p53 expression was not $(P=0.393) . \mathrm{p} 53^{+} / \mathrm{bcl}-2^{+}$tumors were associated with higher incidences of high flk-1 expression (14 of 15; $93.3 \%$ ) and a KI of $85 \%$ or more (11 of $15 ; 73.3 \%$ ) compared with $\mathrm{p} 53^{-} / \mathrm{bcl}-2^{-}$tumors $(3$ of $7 ; 42.9 \% ; P=$ 0.021 , and 1 of $7 ; 14.3 \% ; P=0.020$, respectively) (Table 3 , Fig. 2). There were no differences in the incidences of high VEGF expression and an MVD of 15 or more between $\mathrm{p} 53^{+} / \mathrm{bcl}-2^{+}$tumors (13 of $15 ; 86.7 \%$ and 13 of $15 ; 86.7 \%)$ and $\mathrm{p} 53^{-} / \mathrm{bcl}-2^{-}$tumors $(7$ of $7 ; 100 \%$ and 7 of $7 ; 100 \%)$ respectively ( $P \geq 1.000$; Table 3 , Fig. 2$)$.

Sex, age, CEA, tumor number, largest size, lobar distribution, differentiation, and type of hepatic metastases showed no association with VEGF/flk-1, p53, and/or bcl-2 expression $(P>0.05)$.

\section{Discussion}

It is widely accepted that angiogenesis is essential for tumor progression and the development of metastasis. ${ }^{1}$

Table 2. Relationship between VEGF/flk-1 expression and clinical or immuno-histochemical markers

\begin{tabular}{|c|c|c|c|c|c|}
\hline & \multicolumn{2}{|c|}{ VEGF } & \multicolumn{2}{|c|}{ flk-1 } & \multirow{2}{*}{$\frac{P \text { value }}{\text { VEGF, flk-1 }}$} \\
\hline & Low $(-/ 1+)$ & $\operatorname{High}(2+/ 3+)$ & Low $(-/ 1+)$ & $\operatorname{High}(2+/ 3+)$ & \\
\hline \multicolumn{6}{|c|}{ Differentiation } \\
\hline Poor & 3 & 5 & 3 & 5 & \multirow[t]{2}{*}{$0.117,0.661$} \\
\hline Moderate & 3 & 24 & 7 & 20 & \\
\hline \multicolumn{6}{|l|}{ Tumor size } \\
\hline$<4 \mathrm{~cm}$ & 3 & 10 & 4 & 9 & \multirow[t]{2}{*}{$0.648,1.000$} \\
\hline$\geq 4 \mathrm{~cm}$ & 3 & 19 & 6 & 16 & \\
\hline \multicolumn{6}{|l|}{ MVD } \\
\hline$<15$ & 3 & 2 & 4 & 1 & \multirow[t]{2}{*}{$0.026,0.017$} \\
\hline$\geq 15$ & 3 & 27 & 6 & 24 & \\
\hline \multicolumn{6}{|l|}{ KI } \\
\hline$<50 \%$ & 2 & 0 & 2 & 0 & \multirow[t]{2}{*}{$0.025,0.076$} \\
\hline$\geq 50 \%$ & 4 & 29 & 8 & 25 & \\
\hline \multicolumn{6}{|l|}{ p53 } \\
\hline Negative & 0 & 9 & 4 & 5 & \multirow[t]{2}{*}{$0.304,0.393$} \\
\hline Positive & 6 & 20 & 6 & 20 & \\
\hline \multicolumn{6}{|l|}{ bcl-2 } \\
\hline Negative & 4 & 14 & 9 & 9 & \multirow[t]{2}{*}{$0.658,0.007$} \\
\hline Positive & 2 & 15 & 1 & 16 & \\
\hline
\end{tabular}

MVD, microvessel density; KI, Ki-67 index

Table 3. Relationship between $\mathrm{p} 53 / \mathrm{bcl}-2$ coexpression and the incidences of high VEGF/flk-1 expression, MVD $\geq 15$, and KI $\geq$ $85 \%$

\begin{tabular}{|c|c|c|c|c|c|}
\hline & $\begin{array}{c}n(\%) \\
(\text { Total } n=35)\end{array}$ & $\begin{array}{l}\text { High VEGF } \\
\quad(2+/ 3+)\end{array}$ & $\begin{array}{l}\text { High flk-1 } \\
(2+/ 3+)\end{array}$ & $M V D \geq 15$ & $\mathrm{KI} \geq 85 \%$ \\
\hline $\mathrm{p} 53^{+} / \mathrm{bcl}-2^{+}$ & $15(42.9 \%)$ & $13(86.7 \%)$ & $14(93.3 \%)$ & $13(86.7 \%)$ & $11(73.3 \%)$ \\
\hline p53-/bcl-2- & $7(20.0 \%)$ & $7(100 \%)$ & $3(42.9 \%) *$ & $7(100 \%)$ & $1(14.3 \%)^{* *}$ \\
\hline
\end{tabular}

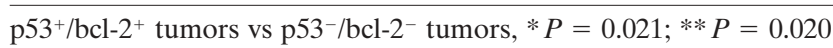




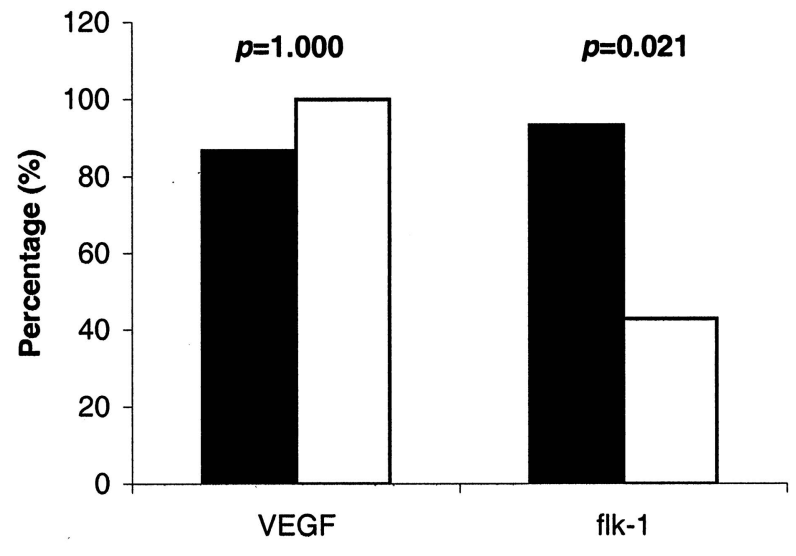

A.

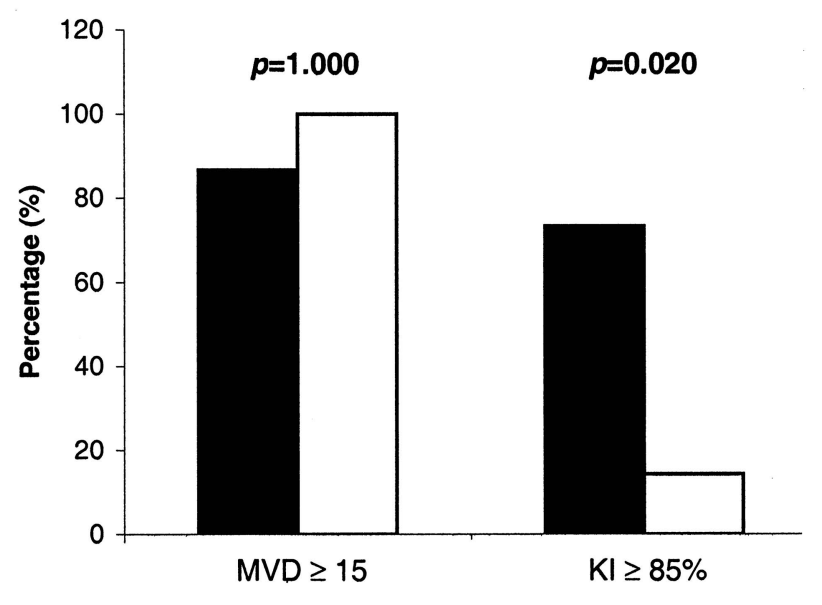

Fig. 2A,B. The incidences of high VEGF or flk-1 expression (A) and MVD $\geq 15$ or Ki-67 index (KI) $\geq 85 \%$ (B) relative to $\mathrm{p} 53^{+} / \mathrm{bcl}-2^{+}$(black bars) and $\mathrm{p} 53^{-} / \mathrm{bcl}-2^{-}$(white bars) tumors

A higher degree of tumor vascularization increases the likelihood that tumor cells will enter the circulatory system and successfully metastasize. VEGF and its receptors play an important role in the induction of tumor angiogenesis. VEGF overexpression has been reported in a variety of solid tumors, including breast, bladder, renal, gastric, colorectal, liver, and pancreatic carcinomas. ${ }^{7,15}$ Several studies have shown that VEGF expression is related to the presence of vascular invasion and liver metastasis in colon cancer. ${ }^{7,14}$ Traditionally, VEGF is thought to act in a paracrine manner via its receptors flt- 1 and flk- 1 , which are both predominantly expressed in endothelial cells. ${ }^{16,17}$ flk-1 is a major regulatory of VEGF-receptor interaction and induces tumor growth and angiogenesis. ${ }^{18}$

Coexpression of VEGF and flk-1 has been identified in human pancreatic and prostate cancer cells by immunohistochemical studies. ${ }^{17,19}$ An in vitro study has also shown that flk-1 mediates the mitogenic function in response to VEGF, and dominant-negative flk-1 results in disruption of VEGF-mediated signal transduction in pancreatic cancer cell lines. ${ }^{17}$ These observations imply the existence of a VEGF-flk-1 autocrine loop with a direct mitogenic effect in tumor cells. In our study, we found that both VEGF and flk-1 were coexpressed in tumor cells, in addition to endothelial cells, in colon hepatic metastases. High levels of VEGF and flk-1 expression occurred in $82.9 \%$ and $71.4 \%$ of tumors, respectively. Higher VEGF expression was associated with higher flk-1 expression $(P=0.043)$. These findings support the idea that the VEGF-flk-1 system works not only via a paracrine loop but also through an autocrine pathway in hepatic metastases from colon cancer.

The extent of MVD correlates with tumor angiogenesis and hematogenous metastasis of colorectal cancer. ${ }^{7,13,14,20,21}$ Patients with synchronous colon carcinoma metastasis have higher vessel counts in their primary tumor than patients with no clinical metastasis. ${ }^{20,21}$ There is a direct correlation between the expression of VEGF, vessel counts, and the development of metastases..$^{20,21}$ Studies have demonstrated that both the microvessel count and VEGF expression are prognostic indicators in colorectal cancer. ${ }^{21,22} \mathrm{Ki}-67$ proliferative activity is inversely correlated with overall and diseasefree survivals. ${ }^{10}$ Our results showed that VEGF/flk-1 expression was related to MVD. VEGF expression was also associated with a high KI. These findings suggest that VEGF and/or flk-1 are involved in regulating the angiogenesis and proliferation of hepatic metastases from colon cancer, and VEGF-expressing tumor cells have a proliferation advantage. Although the association of flk-1 and KI did not reach statistical significance in our study ( $P=0.076$; Table 2$)$, this may be due to the small number of cases examined.

Mutation in p53 and aberrant expression of bcl-2 allow continued tumor proliferation and inhibition of apoptosis. ${ }^{23}$ Coexpression of the bcl-2 and mutant p53 proteins was detected in 38\% of primary colon cancers. ${ }^{6}$ In $62.9 \%$ of our patients, both p53 and bcl-2 were either identified or absent. Mutant p53 upregulates VEGF and diminishes angiogenesis inhibitor thrombospondin-1. ${ }^{1,9}$ Reintroduction of the wild-type p53 gene into colon cancer cells results in a dose-dependent decrease in VEGF mRNA and protein expression. ${ }^{24}$ There is an association between overexpression of mutant $\mathrm{p} 53$ protein, increased MVD, tumor growth, and VEGF expression in colon cancer. ${ }^{7}$ Kang et al. ${ }^{14}$ reported that p53 and VEGF staining status were identical in $65.6 \%$ of colorectal carcinomas, and suggested that a p53-VEGF pathway regulates the angiogenesis of colon carcinoma. Other studies have not confirmed these relationships. ${ }^{12}$ We found that $\mathrm{p} 53$ was not statistically associated with VEGF and flk-1 
expression. Although bcl-2 expression was not related to VEGF, bcl-2 was associated with flk-1 expression $\left(P=0.007\right.$; Table 2). p53 ${ }^{+}$and high VEGF expression coincided in 20 of $35(57.1 \%)$ tumors. $553^{+} / \mathrm{bcl}-2^{+}$tumors had significantly higher incidences of high flk-1 expression $(93.3 \%)$ and a KI of $85 \%$ or more $(73.3 \%)$

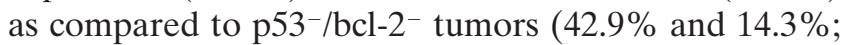
$P \leq 0.021)$. However, there were no differences in the incidences of high VEGF expression and an MVD of 15 or more between $\mathrm{p} 53^{+} / \mathrm{bcl}-2^{+}$and $\mathrm{p} 53^{-} / \mathrm{bcl}-2^{-}$tumors (Table 3 and Fig. 2). These findings suggest that p53 is not the sole regulator of VEGF. Different pathways may exist for dissimilar tumor phenotypes. p53 and bcl2 may work together to regulate flk-1 expression and tumor proliferation in colon hepatic metastasis. This further supports the idea that VEGF may prevent tumor cell apoptosis via the bcl-2 anti-apoptotic pathway, and this event may be mediated through the flk-1 receptor. ${ }^{3}$ Bruns et al. ${ }^{3}$ demonstrated that tumor apoptosis could not be prevented when flk-1 was inactivated in a murine model.

In summary, hepatic metastases from colon cancer were found to express VEGF and flk-1 that related to tumor angiogenesis, proliferation, and apoptosis. High levels of VEGF expression were associated with high levels of flk-1 expression, consistent with the hypothesis that tumor developopment may be stimulated by the VEGF-flk-1 autocrine system. bcl-2 expression and the coincidence of $\mathrm{p} 53$ and bcl-2 were associated with flk-1 expression. This suggests that p53 and bcl-2, especially through the bcl-2 anti-apoptosis pathway, may mediate tumor development via flk-1 to upregulate VEGF function. A large sampling study is warranted to clarify the interaction of VEGF/flk-1 expression with bcl-2 and p53, and its clinical significance, in colon cancer liver metastases.

Acknowledgments. This work was supported by a research grant from Legacy Minimally Invasive Surgery Program, Portland, Oregon. We thank Dr. David Owen, Vancouver General Hospital, British Columbia, Canada; Drs. Christopher Lim and June Olson, Providence Portland Medical Center; and Drs. Christopher Corless and Robert O'Rourke, Oregon Health Science University, for helpful support.

\section{References}

1. Kerbel R, Folkman J (2002) Clinical translation of angiogenesis inhibitors. Nat Rev Cancer 2:727-739

2. Hanahan D, Folkman J (1996) Patterns and emerging mechanisms of the angiogenic switch during tumorigenesis. Cell 86:353364

3. Bruns CJ, Lin W, Davis DW, Shaheen RM, McConbkey DJ, Wilson MR, Bucana CD, Hicklin DJ, Ellis LM (2000) Vascular endothelial growth factor is an in vivo survival factor for tumor endothelium in a murine model of colorectal carcinoma liver metastases. Cancer 89:488-499

4. Yoshiji H, Kuriyama S, Hicklin DJ, Huber J, Yoshii J, Miyamoto Y, Kawata M, Ikenaka Y, Nakatani T, Tsujinoue H, Fukui H (1999) KDR/Flk-1 is a major regulator of vascular endothelial growth factor-induced tumor development and angiogenesis in murine hepatocellular carcinoma cells. Hepatology 30:1179-1186

5. Millauer B, Shawver LK, Plate KH, Risau W, Ullrich A (1994) Glioblastoma growth inhibited in vivo by a dominant-negative flk-1 mutant. Nature 367:576-579

6. Sinicrope FA, Fuan SB, Cleary KR, Stephens LC, Lee JJ, Levin B (1995) bcl-2 and p53 oncoprotein expression during colorectal tumorigenesis. Cancer Res 55:237-241

7. Takahashi Y, Bucana CD, Cleary KR, Ellis LM (1998) p53, vessel count, and vascular endothelial grwoth factor expression in human colon cancer. Int J Cancer 79:34-38

8. Kieser A, Weich HA, Brandner G, Marme D, Kolch W (1994) Mutant p53 potentiates protein kinase $\mathrm{C}$ induction of vascular endothelial growth factor expression. Oncogene 9:963-969

9. Dameron KM, Volpert OV, Tainsky MA, Bouck N (1994) Control of angiogenesis in fibroblasts by p53 regulation of thrombospondin-1. Science 265:1582-1584

10. Weber JC, Nakano H, Bachellier P, Oussoultzoglou E, Inoue K, Shimura H, Wolf P, Chenard-Neu MP, Jaeck D (2001) Is a proliferation index of cancer cells a reliable prognostic factor after hepatectomy in patients with colorectal liver metastases? Am J Surg 182:81-88

11. Chao C, Al-Saleem T, Brooks JJ, Rogatko A, Kraybill WG, Eisenberg B (2001) Vascular endothelial growth factor and soft tissue sarcomas: tumor expression correlates with grade. Ann Surg Oncol 8:260-267

12. Weidner N, Semple JP, Welch WR, Folkman J (1991) Tumor angiogenesis and metastasis-correlation in invasive breast carcinoma. N Engl J Med 324:1-8.

13. Vermeulen PB, Van den Eynden GG, Huget P, Goovaerts G, Weyler J, Lardon F, Van Marck E, Hubens G, Dirix LY (1999) Prospective study of intratumoral microvessel density, p53 expression and survival in colorectal cancer. Br J Cancer 79:316-322

14. Kang SM, Maeda K, Onoda N, Chung YS, Nakata B, Nishiguchi Y, Sowa M (1997) Combined analysis of p53 and vascular endothelial growth factor expression in colorectal carcinoma for determination of tumor vascularity and liver metastasis. Int $\mathbf{J}$ Cancer 74:502-507

15. Yamaguchi R, Yano H, Iemura A, Ogasawara S, Haramaki M, Jojiro M (1998) Expression of vascular endothelial growth factor in human hepatocellular carcinoma. Hepatology 28:6877

16. Fong TA, Shawver LK, Sun L, Tang C, App H, Powell TJ, Kim YH, Schreck R, Wang X, Risau W, Ullrich A, Hirth KP, McMahon G (1999) SU5416 is a potent and selective inhibitor of the vascular endothelial growth factor receptor (flk-1/KDR) that inhibits tyrosine kinase catalysis, tumor vascularization, and growth of multiple tumor types. Cancer Res 59:99-106

17. Von Marschall Z, Cramer T, Hocker M, Burde R, Plath T, Schirner M, Heidenreich R, Breier G, Riecken EO, Wiedenmann B, Rosewicz S (2000) De novo expression of vascular endothelial growth factor in human pancreatic cancer: evidence for an autocrine mitogenic loop. Gastroenterology 119:1358-1372

18. Kim KJ, Li B, Winer J, Armanini M, Gillett N, Phillips HS, Ferrara N (1993) Inhibition of vascular endothelial growth factorinduced angiogenesis suppresses tumour growth in vivo. Nature 362:841-844

19. Kollermann J, Helpap B (2001) Expression of vascular endothelial growth factor (VEGF) and VEGF receptor flk-1 in benign, premalignant, and malignant prostate tissue. Am J Clin Pathol 116:115-121

20. Takahashi Y, Kitadai Y, Bucana CD, Cleary KR, Ellis LM (1995) Expression of vascular endothelial growth factor and its receptor, 
KDR, correlates with vascularity, metastasis, and proliferation of human colon cancer. Cancer Res 55:3964-3968

21. Takahashi Y, Tucker SL, Kitadai Y, Koura AN, Bucana CD, Cleary KR, Ellis LM (1997) Vessel counts and expression of vascular endothelial growth factors as prognostic factors in nodenegative colon cancer. Arch Surg 132:541-546

22. Karayiannakis AJ, Syrigos KN, Zbar A, Baibas N, Polychronidis A, Simopoulos C, Karatzas G (2002) Clinical significance of preoperative serum vascular endothelial growth factor levels in patients with colorectal cancer and the effect of tumor surery. Surgery 131:548-555
23. Tanimoto T, Tanaka S, Haruma K, Yoshihara M, Sumii K, Kajiyama G, Shimamoto F (1998) Growth patterns in various macroscopic types of noninvasive intramucosal colorectal carcinoma with special reference to apoptosis and cell proliferation. Dis Colon Rectum 41:1376-1384

24. Rouvet M, Ellis LM, Nishizaki M, Fujiwara T, Liu W, Bucana CD, Fang B, Lee JJ, Roth JA (1998) Adenovirus-mediated wildtype p53 gene transfer down-regulates vascular endothelial growth factor expression and inhibits angiogenesis in human colon cancer. Cancer Res 58:2288-2292 